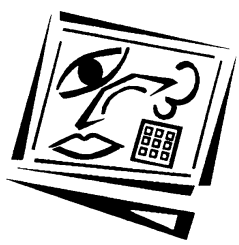

\title{
Blended learning environments: Using social networking sites to enhance the first year experience
}

\author{
Joshua McCarthy \\ The University of Adelaide
}

\begin{abstract}
This study explores blending virtual and physical learning environments to enhance the experience of first year by immersing students into university culture through social and academic interaction between peers. It reports on the progress made from 2008 to 2009 using an existing academic platform, the first year design elective course Imaging Our World, in the School of Architecture, Landscape Architecture and Urban Design at the University of Adelaide. Over one semester, 120 design students, including 27 internationals, engaged with their peers through an online forum within the host site Facebook, in addition to the traditional teaching mechanisms of lectures and tutorials. Students were required to submit work online to Facebook and provide critiques of peers' submissions. Resulting discussions were then transferred into the physical classroom with the aim of building meaningful relationships between peers based on the embryonic online connections. The evaluation process involved pre and post semester questionnaires, weekly feedback from students and project-specific reflections at the completion of the semester. The findings are discussed in light of the conflicting attitudes and assumptions regarding the 'digital native' student cohort, and the use of social media to support learning and teaching in higher education.
\end{abstract}

\section{Introduction}

\section{Who are we teaching?}

In order to engage a cohort of students, it is crucial to understand their backgrounds, and their attitudes towards both academic and social life. How students interact with peers and immerse themselves within education varies from generation to generation, and as such the educator must acknowledge and utilise these nuances rather than disregard them. The cohort involved in this study was predominantly made up of school leavers $(83 \%)$, of largely equal gender composition (54\% male), and a mix of local $(77 \%)$ and international $(23 \%)$ students. The cohort fits within the Generation-Y label, or as Prensky has branded them, the 'digital natives'.

According to Prensky, digital natives have "spent their entire lives surrounded by and using computers, videogames, digital music players, video cams, cell phones, and all the other toys and tools of the digital age" (Prensky, 2001a, p. 1). He maintains that the digital culture and environment in which the Natives have grown up has changed the way they think: "It is now clear that as a result of this ubiquitous environment and the sheer volume of their interaction with it, today's students think and process information fundamentally differently from their predecessors." (Prensky, 2001a, p. 1). As such the argument stands that the digital culture in which the digital natives have grown up has influenced their preferences and skills in a number of key areas related 
to education. Prensky notes, "our students are clamouring for these [new] technologies to be used as part of their education, in part because they are things that the students have already mastered and use in their daily lives, and in part because they realise just how useful they can be." (Prensky, 2007; p. 41, Oblinger, 2003). Supporting literature also suggests digital natives prefer receiving information quickly; are adept at processing information rapidly; prefer multi-tasking and non-linear access to information; have a low tolerance for lectures; prefer active rather than passive learning, and rely heavily on communications technologies to access information and to carry out social and professional interactions (Oblinger, 2003).

In a broad sense, many of Prensky's claims ring true. Technology has become an increasingly prevalent part of day to day life for the modern student. An exponential influx of mobile phones, mp3 players, personal computers and other assorted digital toys have shaped the lives of many students, however to label an entire generation as 'digital natives' is a bold declaration indeed. Furthermore his analysis of lecturers in higher education as 'digital immigrants', foreigners in the digital lands of Generation$Y$, unsurprisingly has attracted much scrutiny from academics within higher education circles (Doherty, 2005; Kennedy et al, 2008). In an extensive study conducted in 2006 with more than 2,000 first-year Australian university students, Kennedy, found that while some students have embraced the technologies and tools of the 'net generation', it was by no means the universal student experience (Kennedy et al, 2008). The study showed a distinct lack of cohesion in the student population with regards to technology, and a potential 'digital divide' between students within a cohort of a single year level.

Moreover, it is increasingly recognised that while the majority of incoming university students possess a core set of technology based skills, there are students with a diverse range of skills across the student population (Caruso, 2005). As Lorenzo states, "today's students are not just the traditional-age net generation, nor have they all had the benefit of state-of-the-art, ubiquitous technology. Higher education comprises a highly diverse and growing student body with a wide variety of information literacy capabilities" (Lorenzo et al, 2006). Bennett, Maton and Kervin (2008) liken Prensky's claims to an 'academic moral panic,' proposing a more measured and disinterested approach is required to examine 'digital natives' and their implications for education. This is supported by Cuban (2001), who suggests that advocates making claims with minimal supporting empirical evidence, are adding to the danger of new technologies, hailed as the tools for educational revolution, failing to meet unrealistic expectations.

\section{Web 2.0 in design education}

Web 2.0 technologies, the participatory web, including social network sites (SNSs) such as Facebook and MySpace, and content-sharing sites such as YouTube and Flickr, allow individuals to present themselves, articulate their social networks, and establish or maintain connections with others. SNSs are amongst the most visited sites on the Internet, with Generation-Y at the forefront of the popularity surge around the world. However, Facebook, currently the most used global social networking website with over $400,000,000$ active users, has not been widely used in tertiary education beyond basic marketing strategies such as universities presenting themselves to prospective students. In spite of this, Facebook's intuitive interface and popularity makes it a very effective tool for developing 'preliminary' relationships between all first year students as it negates key pitfalls such as language barriers and social inhibitions. It allows users to set up a personal page, including personal information, photos, videos, text, 
and a 'wall' for 'friends' to post information on. Users can add 'friends', create networks, groups and events, and link to professional sites, and as such, create an effective online presence. Users can also design and develop in-house applications that interact with core Facebook features.

In an online learning and teaching environment, students are able to communicate at their own pace and consider comments and responses, rather than being 'put on the spot' in the physical classroom. This was the context for the development of an assessment task that would both educate and assimilate. The success of this tool would lie in the extent to which the initial communication and relationships generated in the virtual environment could be taken into the classroom. Facebook was chosen as the host site for the assessment task because of the uniform strength of its features as compared to other popular social networking sites such as MySpace and Friendster, the imagesharing site Flickr, and the open source software Moodle. The site's immense popularity ensured that a large number of students would already be familiar with its layout and operation, and would be comfortable utilising it during the semester, a most important factor in the choosing of a host site, given the potential for a 'digital divide' within the student cohort.

Similarly, it was expected that students would be more inclined to participate in the assessment if it was hosted by a site they already intended to visit repeatedly; this criterion told greatly against the use of learning management systems (LMS), such as MyUni or Moodle, which would have resulted in an independent university site. The 'group' and 'event' applications with Facebook enabled the creation of an accessible, easily maintained, and highly interactive online forum, while lastly, the 24/7 availability of the site conformed with the 'anytime, anywhere' work attitude of Generation-Y students, as Krause notes: "while we recognize that ICT use is by no means synonymous with engagement, the unique communicative capabilities of the technology as well as its increasingly ubiquitous 'anywhere-anytime' qualities offer much to those seeking ways to optimize student engagement in the 21st century" (Krause, 2004). The benefits of online social networking within an academic framework are also evident in Krause's research as she notes that those students reporting the greatest level of satisfaction with their academic progress were typically the ones interacting with peers most regularly and in the widest range of social and academic contexts.

Facebook and other Web 2.0 technologies are not always appropriate or successful vehicles for formal teaching and learning activities. Some studies have suggested that the ways in which students use technologies in their everyday interactions with family and friends may often be different from their preferences for technology use in formal learning settings (Waycott, Bennett, Kennedy, Dalgarno \& Gray, 2010). Salaway, Caruso and Nelson (2007) found that some students were concerned the use of online learning environments might 'eclipse valuable face-to-face interaction with instructors' (p13). Lohnes and Kinzer (2007) observed that some students were resistant to the use of such technologies in the classroom, when a student's use of a private laptop in class was seen as antisocial - 'a barrier to creating and maintaining the classroom community' (p3). While these factors need to be considered, the use of personal laptops within a design-based studio is nationally and internationally commonplace. In any design field students must be up to date with both contemporary software packages and online communication tools, and as such, computer-based learning is an integral part of the student experience. 
It is important that new technologies are integrated into learning and teaching only when driven by pedagogy, rather than technology for technology's sake. As Cluett (2010) notes, launching a university presence on a publicly available sites creates significant challenges and risks. Cyber-bullying and privacy, perhaps the most prevalent risks, can be dealt with using Facebook's administrative rules and toolsets. Page administrators (i.e. course coordinators) are granted simple and effective options for blocking and reporting users who mistreat others or who post offensive content. Similarly Facebook's terms and conditions, as well as the University's IT policy, ensure any such mistreatment is dealt with appropriately. Individual users (i.e. students and staff members) have access to extended privacy parameters that allow them to share and block any information they choose. As has always been the case, it is the responsibility of the course coordinator to ensure that all students are informed of the terms and conditions that govern the classroom, be it physical or virtual, and that students are expected to engage with the course material and interact with their peers within these rules.

\section{Engaging Generation-Y}

There are many approaches to ensure strong student engagement. Fostering an environment in which students participate actively and develop a sense of belonging in both small and large group settings is highly conducive to effective student interaction, as it is widely acknowledged that peers in the learning community play a critical role in supporting first year students' adjustment to University (Krause, McInnis \& Welle, 2003). By promoting independence and building layered support networks, students are able to make the transition into university culture more efficiently and successfully, ensuring a more positive first year experience. While opportunities to ask questions, contribute to class discussions and critique peers' work are all conducive to student engagement, the research continues to emphasise the value of peer interaction both in and out of the classroom (Krause, 2005). As such, the development of academic connections between peers early in university life can promote social interaction, and Facebook's immersive social and educational toolset serves as a strong starting point for entry level students. The research literature also suggests that online social network tools may be of particular utility for individuals who have difficulties forming and maintaining both strong and weak ties, as it has been shown that some forms of computer-mediated communication can lower barriers to interaction and encourage more self-disclosure (Bargh, McKenna \& Fitzsimons, 2002, Tidwell \& Walther, 2002, Ellison, Steinfeld \& Lampe, 2007). As such, Facebook may enable connections and interactions that would not otherwise occur.

The 2008 pilot study which used the Imaging Our World course as a platform for the introduction of an online learning environment in Facebook, indicated that through the use of such a collaborative learning tool, students were able to engage with their peers and develop some sense of belonging within the learning community (McCarthy, 2009). Students were able to develop academic relationships freed from the constraints of the classroom and their own inhibitions, and over the semester discussions evolved from formal academic critiques to informal social interactions. The Facebook group facilitated peer interaction in the early weeks of the course when it was evident that such interaction would not take place in the classroom. This was highly beneficial given that the research literature widely acknowledges that the more frequently students interact with peers in the learning community in educationally purposeful ways, the more likely they are to engage with their learning, (Krause, 2005). The study, 
however, showed that the relationships formed between peers stayed largely embryonic as there wasn't a consistent or direct link between the two teaching environments. In order to meaningfully engage the student cohort in the learning process, while simultaneously improving the experience of first year university, the relationships formed between peers must evolve beyond a purely virtual setting.

\section{Methodology}

The 2008 pilot study established several ways in which to improve the experience and effectiveness of the course. It was apparent that a much stronger link between in class and online environments needed to be created in order to strengthen the face to face engagements between peers. It is crucial to remember that an online connection is only one factor in forming a meaningful relationship, and that physical interaction with peers is essential for developing the student experience. This factor became the catalyst for blending the two learning environments in 2009. Discussions generated within the online environment were then taken into the physical classroom, be it a lecture or tutorial, and further developed under the direction of the lecturer.

In 2008 it also became evident that the online tasks were most beneficial during the early weeks of semester with participation waning during the latter weeks, possibly due to major assignments, exam revision and other courses. For this reason the Facebook assessment in 2009 was compressed into an intensive 6-week program to capitalise on the initial enthusiasm and interaction of students. 120 students including 27 international students, enrolled in the course Imaging Our World, took part in a presemester survey held in the opening lecture. The survey included three broad types of measures. Firstly information about demographic and other descriptive variables, including gender, age bracket, residency, and student type, was collected, as shown in Table 1.

Table 1: Pre-semester survey, breakdown of student demographics

\begin{tabular}{|l|l|c|c|c|}
\hline \multicolumn{2}{|c|}{ Demographic } & $\begin{array}{c}\text { No. of students } \\
\text { (local) }\end{array}$ & $\begin{array}{c}\text { No. of students } \\
\text { (international) }\end{array}$ & $\begin{array}{c}\text { No of students } \\
\text { (all) }\end{array}$ \\
\hline \multirow{2}{*}{ Gender } & Male & 50 & 15 & 65 \\
\cline { 2 - 5 } & Female & 43 & 12 & 55 \\
\hline \multirow{3}{*}{ Age } & $17-20$ & 83 & 22 & 105 \\
\cline { 2 - 5 } & $21-25$ & 7 & 5 & 12 \\
\cline { 2 - 5 } & $26+$ & 3 & 0 & 3 \\
\hline \multirow{2}{*}{ Sesidency } & Local & 93 & 0 & 27 \\
\cline { 2 - 5 } & International & 0 & 27 & 113 \\
\hline \multirow{3}{*}{ Employment type } & Full time & 87 & 26 & 48 \\
\cline { 2 - 5 } & Part time & 6 & 24 & 38 \\
\cline { 2 - 5 } & $1-10$ & 24 & 2 & 31 \\
\cline { 2 - 5 } & $11-20$ & 36 & 1 & 1 \\
\cline { 2 - 5 } & $21-30$ & 2 & 0 & 2 \\
\cline { 2 - 5 } & $31-40$ & 1 & 0 & \multicolumn{2}{c}{} \\
\hline
\end{tabular}

Secondly, Facebook usage measures were included, such as time spent on the site and items designed to assess the types of connections it was used for, as shown in Tables 2 and 3. Thirdly, the survey included measures to assess the students' attitudes towards 'online' and 'in class' communication with peers. Attitudinal responses were measured using Likert scales from 1-7, and additional, open ended comments were encouraged. 
A two-hour workshop took place in the opening tutorial of the course, allowing inexperienced students to become accustomed with Facebook's layout and operation. Students were shown how to create an account, interact with peers, and take part in the compulsory online assessment. The two-hour session was more than adequate for all students, due to the existing popularity and familiarity of the site within the cohort. The online assessment task included a series of image and video galleries over the sixweek period. For each gallery in Facebook, three in total, students were required to submit images and videos relating to the gallery topic every two weeks, and to provide critiques on peers' submissions. The gallery topics were broad in nature, and open to the student's own interpretations, allowing for a wide range of images in each, and a concurrently wide range of discussions. The galleries were open for content submissions for one week and then critiques the following week, however they remained viewable for the duration of the entire semester. Students had '24/7' access to over 90 computers in two labs and could also access the site and submit work through private Internet connections.

The tasks were worth $15 \%$ of the final grade for the course, and students were assessed on three key components: the relevance and quality of the submitted images and videos, the provided descriptions that accompanied the content, and the quality and consistency of their critiques and subsequent discussions. Students were encouraged to submit original imagery and draw on their own experiences and cultural backgrounds for inspiration, but were permitted to submit non-original material provided it was referenced and not copyrighted. Each week a range of discussions that took place within the virtual gallery were then transferred to the physical classroom, generally a lecture, and further analysed, endeavouring to bring the online interaction into a face to face environment. The discussions selected for further debate were based on demographic equality, specifically gender and ethnicity, and its relevance to the lecture topic at hand. In the final week of the semester, students completed a second survey which assessed their experiences throughout the course and the perceived effectiveness of the virtual and physical classrooms.

\section{Findings}

The 2009 pre-semester survey outlined the student demographic and showed significant shifts in Facebook popularity and usage from the 2008 cohort. Firstly there was a much higher percentage of existing Facebook users within the group, 91\% (Table 2) compared to $75 \%$ in 2008. Given the 'digital divide' found by Kennedy et al (2008) within Generation-Y first year students, this was a positive step forward to successful integration of the Facebook environment into the course. The survey also indicated that $61 \%$ of students logged onto Facebook at least once a day (Table 2) compared to $35 \%$ in 2008. The intensity per visit also increased, with many students indicating they stayed 'actively' logged in for up to an hour, while others stated they often stayed 'inactively' logged into Facebook while browsing other sites. These statistics indicate a possible increase in engagement with the course assessment, and therefore increased interaction with their peers, as students continued to return to Facebook over an extended period of time while online.

The type of use also changed with students indicating they used Facebook more frequently to learn about people they met socially (mean response of 4.1 in 2008 , to 4.9 in 2009 using a Likert scale ranging from 1-7), and in class (3.9 in 2008 to 5.1 in 2009) (Table 3). The mean responses from local and international students were largely 
Table 2: Pre-semester survey, Facebook usage - intensity

\begin{tabular}{|c|c|c|c|c|}
\hline \multicolumn{2}{|c|}{ Question } & $\begin{array}{l}\text { No. of students } \\
\text { (local) }\end{array}$ & $\begin{array}{c}\text { No. of students } \\
\text { (international) }\end{array}$ & $\begin{array}{l}\text { No of students } \\
\text { (all) }\end{array}$ \\
\hline \multirow[t]{2}{*}{ Member of Facebook } & Yes & 88 & 21 & 109 \\
\hline & No & 5 & 6 & 11 \\
\hline \multirow{4}{*}{ No. of friends from IOW } & 0 & 52 & 18 & 70 \\
\hline & $1-5$ & 27 & 3 & 30 \\
\hline & 6-10 & 9 & 0 & 9 \\
\hline & $11+$ & 0 & 0 & 0 \\
\hline \multirow[t]{6}{*}{ Usage intensity } & Several times a day & 20 & 11 & 31 \\
\hline & Once a day & 31 & 5 & 36 \\
\hline & Several times a week & 26 & 3 & 29 \\
\hline & Once a week & 9 & 1 & 10 \\
\hline & Monthly & 1 & 0 & 1 \\
\hline & Rarely & 1 & 1 & 2 \\
\hline \multirow[t]{4}{*}{ Intensity per visit } & 0-10 minutes & 25 & 6 & 31 \\
\hline & 11-30 minutes & 40 & 9 & 49 \\
\hline & 31-60 minutes & 13 & 3 & 16 \\
\hline & $60+$ minutes & 10 & 3 & 13 \\
\hline
\end{tabular}

consistent across the seven topics with one exception relating to the use of Facebook to "learn more about people living in my area." The mean response from international students of 4.5 was significantly greater than that of the local students, 2.7, suggesting that international students saw Facebook as an opportunity to learn about and meet people in their new environment. Not surprisingly there was a continued lack of preexisting social networks within the cohort. The pre-semester survey showed that $64 \%$ of students had no existing Facebook 'friends' from Imaging Our World (IOW), while $97 \%$ had five or less. This can be attributed to the large percentage of school leavers within the group, the range of academic programs the students were enrolled in (within 120 students, 7 University programs were represented), and the large variation of student ethnicities.

Table 3: Pre-semester survey, Facebook usage - type

\begin{tabular}{|l|c|c|c|c|c|c|}
\hline \multicolumn{1}{|c|}{ Question } & $\begin{array}{c}\text { Mean } \\
\text { (local) }\end{array}$ & $\begin{array}{c}\% \text { Broad } \\
\text { agreement }\end{array}$ & $\begin{array}{c}\text { Mean } \\
\text { (int.) }\end{array}$ & $\begin{array}{c}\% \text { Broad } \\
\text { agreement }\end{array}$ & $\begin{array}{c}\text { Mean } \\
\text { (all) }\end{array}$ & $\begin{array}{c}\% \text { Broad } \\
\text { agreement }\end{array}$ \\
\hline $\begin{array}{l}\text { I use Facebook to learn more about } \\
\text { people I meet socially. }\end{array}$ & 5.0 & $77 \%$ & 4.6 & $74 \%$ & 4.9 & $76 \%$ \\
\hline $\begin{array}{l}\text { I use Facebook to learn more about } \\
\text { people in my classes. }\end{array}$ & 5.1 & $80 \%$ & 5.0 & $80 \%$ & 5.1 & $80 \%$ \\
\hline $\begin{array}{l}\text { I use Facebook to learn more about } \\
\text { people living in my area. }\end{array}$ & 2.7 & $21 \%$ & 4.5 & $55 \%$ & 3.1 & $30 \%$ \\
\hline $\begin{array}{l}\text { I use Facebook to stay in touch with } \\
\text { my family. }\end{array}$ & 3.8 & $49 \%$ & 4.1 & $51 \%$ & 3.9 & $49 \%$ \\
\hline $\begin{array}{l}\text { I use Facebook to stay in touch with } \\
\text { my close friends. }\end{array}$ & 5.4 & $80 \%$ & 5.6 & $86 \%$ & 5.4 & $82 \%$ \\
\hline $\begin{array}{l}\text { I use Facebook to find past friends. } \\
\text { I use Facebook to meet new people. }\end{array}$ & 2.9 & $67 \%$ & 5.2 & $80 \%$ & 5.0 & $72 \%$ \\
\hline
\end{tabular}

The post-semester survey revealed the students' attitudes towards both virtual and physical classrooms and their perceptions regarding the successful blending of the two environments. Many students responded positively to the virtual space as it helped negate common first year pitfalls such as language barriers and introversion, as one student noted, "the online galleries were less intimidating than the physical classroom, 
which was particularly important at the start of semester." An international student stated, "I was able to comment on their work at my own pace which made it much more comfortable." The virtual environment helped initiate fledgling connections between students: "as a first year student we don't really know anyone, so the Facebook group was a simple and effective way to start putting names to faces." This proved highly beneficial in the first two weeks as it "established connections throughout the class that may not have otherwise been there." The incorporation of online discussions into the physical classroom proved to be significant in both the development of peer relationships and academic growth, as one student noted:

I really enjoyed this assignment as I find it quite daunting to speak up in front of a whole class, especially if at first you don't know anyone in the class. It was good that the submissions were brought into the classroom the following week, however, because we could talk about the work with an established platform which made it easier to debate in the lecture while also providing a more rewarding discussion.

Further benefits of the blended learning environment were made apparent through attitudinal scales relating to interaction between peers and open ended comments discussing the course. Tables 4 and 5 outline the mean responses and broad agreement percentages of local and international students from the 2008 and 2009 cohorts respectively. The data shows that there was a large increase in the academic interaction between local and international students (mean response of 5.0 in 2008 up to 5.7 in 2009), as well as general interaction, both academic and social, between peers (5.7 in 2008 up to 6.4 in 2009). Many students attributed this to the strong link between virtual and physical spaces as "the discussions that followed also created opportunities to interact with and get to know fellow students."

Table 4: Post-semester survey, peer interaction (academic and social), 2008 cohort

\begin{tabular}{|l|c|c|c|c|c|c|}
\hline \multicolumn{1}{|c|}{ Question } & $\begin{array}{c}\text { Mean } \\
\text { (local) }\end{array}$ & $\begin{array}{c}\text { \% Broad } \\
\text { agreement }\end{array}$ & $\begin{array}{c}\text { Mean } \\
\text { (int.) }\end{array}$ & $\begin{array}{c}\% \text { Broad } \\
\text { agreement }\end{array}$ & $\begin{array}{c}\text { Mean } \\
\text { (all) }\end{array}$ & $\begin{array}{c}\% \text { Broad } \\
\text { agreement }\end{array}$ \\
\hline $\begin{array}{l}\text { The Facebook group and image galleries } \\
\text { in IOW helped me to develop } \\
\text { academic relationships with same- } \\
\text { culture students. }\end{array}$ & 5.6 & $88 \%$ & 5.9 & $91 \%$ & 5.7 & $89 \%$ \\
\hline $\begin{array}{l}\text { The Facebook group and image galleries } \\
\text { in IOW helped me to develop social } \\
\text { relationships with same-culture } \\
\text { students. }\end{array}$ & 5.2 & $82 \%$ & 5.2 & $81 \%$ & 5.2 & $82 \%$ \\
\hline $\begin{array}{l}\text { The Facebook group and image galleries } \\
\text { in IOW helped me to develop } \\
\text { academic relationships with different- } \\
\text { culture students. }\end{array}$ & 5.0 & $80 \%$ & 5.7 & $87 \%$ & 5.2 & $82 \%$ \\
\hline $\begin{array}{l}\text { The Facebook group and image galleries } \\
\text { in IOW helped me to develop social } \\
\text { relationships with different-culture } \\
\text { students. }\end{array}$ & 4.8 & $73 \%$ & 5.1 & $83 \%$ & 4.9 & $76 \%$ \\
\hline $\begin{array}{l}\text { The Facebook group and image galleries } \\
\text { in IOW increased my interaction with } \\
\text { peers. }\end{array}$ & 5.7 & $84 \%$ & 5.5 & $88 \%$ & 5.7 & $85 \%$ \\
\hline $\begin{array}{l}\text { The Facebook group and image galleries } \\
\text { in IOW generated rewarding academic } \\
\text { discussions that benefited my studies } \\
\text { this semester. }\end{array}$ & 5.9 & $90 \%$ & 6.1 & $97 \%$ & 5.9 & $92 \%$ \\
\hline
\end{tabular}


Table 5: Post-semester survey, peer interaction (academic and social), 2009 cohort. Mean responses include increase or decrease from 2008.

\begin{tabular}{|c|c|c|c|c|c|c|}
\hline Question & $\begin{array}{l}\text { Mean } \\
\text { (local) }\end{array}$ & $\begin{array}{c}\% \text { Broad } \\
\text { agreement }\end{array}$ & $\begin{array}{c}\text { Mean } \\
\text { (int.) }\end{array}$ & $\begin{array}{c}\% \text { Broad } \\
\text { agreement }\end{array}$ & $\begin{array}{c}\text { Mean } \\
\text { (all) }\end{array}$ & $\begin{array}{c}\% \text { Broad } \\
\text { agreement }\end{array}$ \\
\hline $\begin{array}{l}\text { The Facebook group and image } \\
\text { galleries in IOW helped me to } \\
\text { develop academic relationships with } \\
\text { same-culture students. }\end{array}$ & $\begin{array}{l}6.5(+0.9 \\
\text { from } \\
2008)\end{array}$ & $95 \%$ & $\begin{array}{c}6.1 \\
(+0.2)\end{array}$ & $91 \%$ & $\begin{array}{c}6.4 \\
(+0.7)\end{array}$ & $93 \%$ \\
\hline $\begin{array}{l}\text { The Facebook group and image } \\
\text { galleries in IOW helped me to } \\
\text { develop social relationships with } \\
\text { same-culture students. }\end{array}$ & $5.2(-)$ & $82 \%$ & $5.2(-)$ & $81 \%$ & $5.2(-)$ & $82 \%$ \\
\hline $\begin{array}{l}\text { The Facebook group and image } \\
\text { galleries in IOW helped me to } \\
\text { develop academic relationships with } \\
\text { different-culture students. }\end{array}$ & $\begin{array}{c}5.7 \\
(+0.7)\end{array}$ & $87 \%$ & $5.7(-)$ & $87 \%$ & $\begin{array}{c}5.7 \\
(+0.5)\end{array}$ & $87 \%$ \\
\hline $\begin{array}{l}\text { The Facebook group and image } \\
\text { galleries in IOW helped me to } \\
\text { develop social relationships with } \\
\text { different-culture students. }\end{array}$ & $\begin{array}{c}4.9 \\
(+0.1)\end{array}$ & $76 \%$ & $\begin{array}{c}5.0 \\
(-0.1)\end{array}$ & $80 \%$ & $4.9(-)$ & $77 \%$ \\
\hline $\begin{array}{l}\text { The Facebook group and image } \\
\text { galleries in IOW increased my } \\
\text { interaction with peers. }\end{array}$ & $\begin{array}{c}6.4 \\
(+0.7)\end{array}$ & $92 \%$ & $\begin{array}{c}6.3 \\
(+0.8)\end{array}$ & $91 \%$ & $\begin{array}{c}6.4 \\
(+0.7)\end{array}$ & $92 \%$ \\
\hline $\begin{array}{l}\text { The Facebook group and image } \\
\text { galleries in IOW generated rewarding } \\
\text { academic discussions that benefited } \\
\text { my studies this semester. }\end{array}$ & $\begin{array}{c}6.3 \\
(+0.4)\end{array}$ & $89 \%$ & $6.1(-)$ & $87 \%$ & $\begin{array}{c}6.3 \\
(+0.4)\end{array}$ & $89 \%$ \\
\hline
\end{tabular}

Students noted the ability to gain "informative and rewarding" feedback from multiple sources as an advantage of the online environment, with students commenting that "constructive comments and healthy discussions improved student creativity and output," and "while the idea of critiquing other students work was foreign to me; after a couple of weeks I got into it and got some great feedback on my submissions." The ability to generate specific academic connections was another rewarding aspect of the online assessment: "the Facebook tasks were great as they provided freedom to express ideas, hence generate discussion as well as finding likeminded peers," while "the Facebook assignment helped the students communicate and change opinions about design - this happened through students supplying suggestions and different opinions about submissions and initiating a dialogue." Many students also commented positively on the ability to express themselves and voice their own opinions about peers' submissions, proving for some to be a "new and enriching" form of interaction.

\section{Discussion}

One of the most rewarding aspects of the online learning environment was the increased interaction between local and international students. Many international students saw the online environment as a perfect opportunity to engage with their peers as they were able to consider their comments and critiques over a period of time rather than being put on the spot in a lecture or tutorial. Language barriers and social inhibitions, often common among commencing international students (Sawir, 2007), were suppressed as "the online forum allowed for good communication between students, particularly local students." The Facebook group and assessment tasks even 
found their way back to some of the international students' home countries with friends from China, Hong Kong and Malaysia participating in the galleries. The response was just as positive from local students who, while indicating they were very keen to engage with students from different cultures, acknowledged this was often hard in traditional learning environments: "sometimes it can be hard interacting with some of the international students because of the language barrier but with Facebook, because it was online, it was really easy and enjoyable - so many different perspectives and opinions coming together."

These connections, made between local and international students in the opening weeks of the course, became more evident in the physical classroom towards the end of the semester as classroom discussions evolved into long debates between students. There were no concerns from students regarding either the use of Web 2.0 technologies within the course or privacy issues, as was found in previous studies (Waycott et al, 2010, Salaway et al, 2007, Lohnes \& Kinzer, 2007). This indicates that such technology is perhaps better suited to educational areas such as design, which are reliant on digital content and communication.

The benefits of the blended learning spaces included face to face discussions: "the assessment allowed us to converse with others in class and form connections that developed into friendships", a factor that came up time and time again within the student cohort: "the best thing about the Facebook galleries was that they got everyone talking from day one - all of sudden I had all these new friends on Facebook and from there had friends in class." Many students also noted a stronger link between design theory and practice: "the lecturer's ability to tie in our work with specific theoretical concepts in class improved my understanding of the course content," and the level of engagement with the cohort, due to its "modern way of interacting and communicating ideas", as another student noted:

This part of the course set it apart from all others. The interactivity of the assessment made it so enjoyable. It was a great way to learn about the other students in the course and it was interesting to use social media as a means of assessment and academic interaction.

Both the 2008 and 2009 studies indicated that the virtual classroom hosted by Facebook, provided a platform for students to generate preliminary academic and social interactions with peers in first year university, while meeting the diverse learning needs and attitudes of Generation-Y students:

It was great to see an innovative idea such as using Facebook for assessment in Uninot what I expected. As I was already a member of Facebook I found the assessment enjoyable and a good opportunity to talk with other students outside of class.

Facebook was the perfect host site for such an environment due to its intuitive interface, existing popularity and ease of use. In 2008 the interactions between peers stayed largely embryonic, due to a disconnection between the virtual and physical learning environments (McCarthy, 2009). A physical classroom allows students to interact in a face to face environment, essentially transforming the often impersonal virtual interaction into a meaningful connection. The 2009 study indicated that the blending of real and virtual environments increased peer interaction and academic engagement, two key factors in a positive first year experience. This teaching approach will continue within Imaging Our World in 2010, while the study will be triangulated in 2011 with first year students on a national and international stage. 


\section{References}

Bargh, J., McKenna, K. \& Fitzsimons, G. (2002). Can you see the real me? Activation and expression of the "true self" on the Internet. Journal of Social Issues, 58(1), 33-48.

Bennett, S., Maton, K. \& Kervin, L. (2008). The 'digital natives' debate: A critical review of the evidence. British Journal of Educational Technology, 39(5), 775-786.

Caruso, J. B. \& Kvavik, R. (2005). ECAR study of students and information technology 2005: Convenience, connection, control, and learning. EDUCAUSE. http: / / www.educause.edu/ECAR/ECARStudyofStudentsandInformat/ 158586

Cluett, L. (2010). Online social networking for outreach, engagement and community: The UWA Students' Facebook page. In Educating for sustainability. Proceedings of the 19th Annual Teaching Learning Forum, 28-29 January 2010. Perth: Edith Cowan University. http: / / otl.curtin.edu.au/tlf/tlf2010/ refereed/cluett.html

Cuban, L. (2001). Oversold and underused: Computers in the classroom. Cambridge, MA: Harvard University.

Doherty, L. (2005). Where worlds collide and pupils leave teachers behind. Sydney Morning Herald, 1 October, 2005. [verified 27 Sep 2010] http: / / www.smh.com.au/news/national/ where-worlds-collide-and-pupils-leave-teachers-behind / 2005/09/30/1127804662694.html

Ellison, N., Steinfeld, C. \& Lampe, C. (2007). The benefits of Facebook "friends": Social capital and college students' use of online social network sites. Journal of Computer-Mediated Communication, 12, 1143-1168. [verified 27 Sep 2010]

http: / jcmc.indiana.edu/vol12/issue4/ellison.html

Kennedy, G., Krause, K., Gray, K., Judd, T., Bennett, S., Maton, K., Dalgarno, B. \& Bishop, A. (2006). Questioning the Net generation: A collaborative project in Australian higher education. In Who's learning? Whose technology? Proceedings ASCILITE 2006. http: / / www.ascilite.org.au/conferences / sydney06/proceeding/pdf_papers/p160.pdf

Kennedy, G., Dalgarno, B., Gray, K., Judd, T., Waycott, J., Bennett, S., Maton, K., Krause, K., Bishop, A., Chang, R. \& Churchward, A. (2007). The Net generation are not big users of Web 2.0 technologies: Preliminary findings from a large cross-institutional study. In ICT: Providing choices for learners and learning. Proceedings ascilite Singapore 2007. http: / / www.ascilite.org.au/conferences / singapore07/ procs/ kennedy.pdf

Kennedy, G., Judd, T., Churchward, A., Gray, K. \& Krause, K. (2008). First year students' experiences with technology: Are they really digital natives? Australasian Journal of Educational Technology, 24(1), 108-122. http:/ / www.ascilite.org.au/ajet/ajet24/ kennedy.html

Krause, K. (2005). The changing student experience: Who's driving it and where is it going? Keynote paper presented at Student Experience Conference: Good Practice in Practice, 5-7 September, Charles Sturt University, Wagga Wagga, NSW. [verified 27 Sep 2010] http: / / www.griffith.edu.au/_data/assets / pdf_file/0003/39270/StudExpKeynote05.pdf

Krause, K. \& Duchesne, S. (2000). With a little help from my friends: Social interactions on campus and their role in the first year experience. Paper presented at the Fourth Pacific Rim Conference: First Year in Higher Education - Creating futures for a new millennium, 5-7 July, Brisbane. [verified 27 Sep 2010] http:/ / www.fyhe.com.au/past_papers/papers/KrausePaper.doc

Krause, K., Hartley, R., James, R. \& McInnis, C. (2005). The first year experience in Australian universities: Findings from a decade of national studies. Canberra: DEST. http:/ / www.dest .gov.au/sectors/higher_education/publications_resources/profiles/first_year_experience.htm

Krause, K., McInnis, C. \& Welle, C. (2003). Out-of-class engagement in undergraduate learning communities: The role and nature of peer interactions. Paper presented at the Association for the Study of Higher Education Conference, 13-16 November, Portland, Oregon, USA. [verified 27 Sep 2010] http: / / www.eric.ed.gov / PDFS / ED482146.pdf 
Krause, K. (2005). Serious thoughts about dropping out in first year: Trends, patterns and implications for higher education. Studies in Learning, Evaluation, Innovation and Development, 2(3), 55-68.

Krause, K. (2006). Making connections in the first year: The key to success in an age on unreason. Keynote paper presented at the 19th International Conference on The First-Year Experience, July, Toronto. http:/ / www.griffith.edu.au/_data/assets / pdf_file/0004/39271/TorontoIFYE2006.pdf

Krause, K. (2006). Transition to and through the first year: Strategies to enhance the student experience. Keynote paper presented at the Inaugural Vice-Chancellor's Learning and Teaching Colloquium, 31 May, University of the Sunshine Coast, Queensland, Australia. http://www.griffith.edu.au/_data/assets/pdf_file/0008/39275/USCKeynoteFinal2006.pdf

Lohnes, S. \& Kinzer, C. (2007). Questioning assumptions about students' expectations for technology in college classrooms. Innovate, 3(5). http:/ / innovateonline.info/pdf/vol3_issue5/ Questioning_Assumptions_About_Students'_Expectations_for_Technology_in_College_Classrooms.pdf

Lorenzo, G., Oblinger, D. \& Dziuban, C. (2006). How choice, co-creation, and culture are changing what it means to be net savvy. EDUCAUSE Quarterly, 30(1). http:/ / connect.edu cause.edu / Library / EDUCAUSE+Quarterly / HowChoiceCoCreationandCul / 40008

McCarthy, J. (2009). Utilising Facebook: Immersing Generation-Y students into first year university. ergo, 1(2), 39-49. [verified 27 Sep 2010] http: / / digital.library.adelaide.edu.au/dspace/bitstream/2440/49880/1/hdl_49880.pdf

Oblinger, D. (2003). Boomers, Gen-Xers \& Millennials. Understanding the new students. EDUCAUSE Review, 38(4), 37-47. http:/ / www.educause.edu/ir/library/pdf/ERM0342.pdf

Prensky, M. (2001a). Digital natives, digital immigrants. On The Horizon, 9(5). http:/ / www.marc prensky.com/writing/Prensky\%20-\%20Digital\%20Natives,\%20Digital\%20Immigrants\%20-\%20Part1.pdf

Prenksy, M. (2001b). Digital natives, digital immigrants, Part II. Do they really think differently? On the Horizon, 9(6). http: / / www.marcprensky.com/ writing/Prensky\%20$\% 20$ Digital\%20Natives,\%20Digital\%20Immigrants\%20-\%20Part2.pdf

Prensky, M. (2007). How to teach with technology: Keeping both teachers and students comfortable in an era of exponential change. Emerging Technologies for Learning, Vol.2. [verified 27 Sep 2010] http:/ / partners.becta.org.uk/page_documents / research/ emerging_technologies07_chapter4.pdf

Salajan, F., Schonwetter, D. \& Cleghorn, B. (2010). Student and faculty inter-generational digital divide: Fact or fiction? Computers \& Education, 55, 1393-1403.

Salaway, G., Carusio, J. \& Nelson, M. (2007). The ECAR study of undergraduate students and information technology, 2007. Boulder, Colorado: EDUCAUSE Center for Applied Research. http: / / www.educause.edu/ECAR/TheECARStudyofUndergraduateStu / 161967

Sawir, E., Marginson, S., Deumert, A., Nyland, C. \& Ramia, G. (2007). Loneliness and international students: An Australian study. Journal of Studies in International Education, 12 (2), 148-180.

Waycott, J., Bennett, S., Kennedy, G., Dalgarno, B. \& Gray, K. (2010). Digital divides? Student and staff perceptions of information and communication technologies. Computers $\mathcal{E}$ Education, 54, 1202-1211.

Mr Josh McCarthy, Lecturer, School of Architecture, Landscape Architecture and Urban Design, University of Adelaide, Adelaide SA 5005, Australia

Email: joshua.mccarthy@adelaide.edu.au

Web: http: / / www.adelaide.edu.au/directory/joshua.mccarthy 